\title{
KEGIATAN PEMBELAJARAN BERTANI PADA SISWA TUNANETRA DI SLB AGRO INDUSTRI CISARUA KABUPATEN BANDUNG BARAT
}

\author{
Ira Ariyanti, Juang Sunanto, Ahmad Nawawi \\ Universitas Pendidikan Indonesia \\ iraariyanti@upi.edu; juangsunanto@upi.edu; ahmadnawawi@upi.edu
}

\begin{abstract}
This study examines the learning activities farming in the blind students in SLB Agro Industry. This study aims to describe the learning activities farming in the blind students in SLB Agro Industries Cisarua, West Bandung regency. Descriptive research methods - qualitative. Data was collected through interviews, observation, and documentation with triangulation techniques. Analysis of the data by reduction, display, conclusions, and verification. Research subjects in this study consisted of principals, teachers, students, and parents. The results of this study indicate that outlines the vision; mission SLB Agro Industry stressed the independence of the learners to adapt to the environment. Then curriculum applied that functional curriculum, while the agricultural curriculum refers to the agriculture vocational curriculum tailored to the needs and abilities of learners. Human resources involved in the eight-man special education teachers certified S1, some experts manager learning programs are also certified $S 1$ farming and some citizens. Responses learners on learning activities have been fun, though the lack of theory given constraints. The response of parents can be quite good because it is often involved in school activities. The neighborhood around the school or community support and engage in activities in the SLB Agro Industries, even there are also some of this Agreement.
\end{abstract}

Keywords: Teaching and Bertani, SLB Agro Industries, Blind Students

\section{A. PENDAhULUAN}

Pendidikan merupakan suatu kebutuhan utama setiap manusia dalam kehidupan. Hal ini dikarenakan pendidikan dapat mengembangkan potensi diri agar dapat bertahan hidup. Menyikapi pentingnya pendidikan dalam pengembangan potensi diri seseorang, maka pendidikan hendaknya dapat melihat semua unsur yang ada sebagai sebuah kesatuan yang saling mempengaruhi satu sama lain sehingga dapat mencapai suatu mutu pendidikan. Selain itu, pendidikan nasional yang diprogramkan oleh negara harus diarahkan dengan tepat kepada setiap warga negara sehingga setiap warga negara mendapatkan pelayanan pendidikan yang bermutu dan berkualitas, seperti yang tertuang pada UU No.20 Tahun 2003 tentang Sistem Pendidikan Nasional Pasal 5 ayat 1 bahwa setiap warga negara mempunyai hak yang sama untuk memperoleh pendidikan yang bermutu. Kegiatan bertani dirasa cukup penting bagi bekal kehidupan setiap manusia, termasuk bagi Anak Berkebutuhan Khusus (ABK). Kemampuan bertani bagi ABK ini diharapkan dapat dijadikan suatu usaha yang dapat menghasilkan sesuatu bagi kehidupannya. Selain itu, kemampuan tersebut diharapkan dapat memperluas kesempatan $\mathrm{ABK}$ untuk dapat hidup mandiri di tengah kehidupan masyarakat.Selain kedua hal tersebut, kemampuan bertani 
dirasakan penting dikarenakan negara Indonesia yang dapat dikatakan sebagai negara agraris sehingga keterampilan bertani yang memegang peranan penting dalam perekonomian nasional. Selain itu, keterampilan bertani merupakan salah satu cara untuk bertahan hidup yang bisa dilakukan semua orang, baik itu orang yang ekonominya di atas rata-rata maupun di bawah rata-rata.

Kegiatan bertani disini diartikan sebagai upaya manusia terhadap proses pengendalian produk biologis yang terjadi di alam, mencakup pengendalian pertumbuhan tanaman, peternakan dan perikanan. Sehingga hasil dari proses tersebut dapat memberikan manfaat yang lebih baik dan dapat memenuhi kebutuhan hidup serta dapat meningkatkan penghasilan para petani untuk dapat bertahan hidup. Dalam keterampilan bertani terdapat beberapa hal yang harus diperhatikan, diantaranya iklim, tanah, aturan atau cara kegiatan bertani seperti pengolahan tanah, pembibitan, penanaman, dan pemungutan hasil tani. Berdasarkan pemikiran di atas, maka penulis bermaksud melakukan penelitian mengenai "Kegiatan PembelajaranBertani pada siswa Tunanetra di SLB Agro Industri Cisarua Kabupaten Bandung Barat."

\section{B. KAJIAN LITERATUR}

Sekolah Luar Biasa (SLB) merupakan suatu lembaga pendidikan formal yang dirancang secara khusus bagi peserta didik usia sekolah yang memiliki tingkat kesulitan dalam mengikuti proses pembelajaran. Hal inidikarenakan kelainan fisik, emosional, mental sosial, dan yang memiliki potensi kecerdasan dan bakat istimewa. Peserta didik tersebut biasa disebut dengan anak berkebutuhan khusus.

Seperti yang dikemukakan oleh Dinas Pendidikan Bidang Pendidikan Luar Biasa (2011, hlm.22) bahwa "SLB merupakan salahsatu lembaga yang sangat strategis dalam membantu mengembangkan potensi, bakat, dan minat anak-anak dengan kebutuhan khusus."

SLB mempunyai tugas pokok membantu anak berkebutuhan khusus (ABK) usia sekolah untuk mencapai perkembangan yang optimal sesuai dengan tingkat dan jenis kelainannya, serta memberikan layanan pembelajaran yang kompleks dan dirancang khusus untuk membantu dan memenuhi kebutuhan peserta didik dalam mengembangkan potensinya secara maksimal. ABK hidup di tengah masyarakat yang terus menerus berkembang, sehingga kebutuhan hidup pun semakin berkembang pula. Hal tersebut menuntut setiap orang termasuk ABK untuk memiliki kemampuan yang dapat dikembangkan agar dapat bertahan hidup. Oleh karena itu kegiatan pembelajaran bagi ABK saat ini seyogyanya lebih ditekankan pada pembelajaran yang dapat memberikan bekal bagi kehidupan ABK, atau pembelajaran yang dapat berfungsi bagi kehidupan ABK. Hal ini ditujukan agar di masa depannya ABK tidak tergantung lagi pada orang lain dan ABK dapat melakukan sesuatu hasil dari pembelajaran untuk memenuhi kebutuhan hidupnya. Salah satu pembelajaran yang dapat dilakukan yaitu dengan melakukan pembelajaran yang langsung dialami oleh peserta didik dan dapat dirasakan juga manfaatnya oleh peserta didik.

Secara umum,pembelajaran yang dilaksanakan di SLB terkadang pembelajaran yang hanya mengembangkan potensi kognitif ABK. Tetapi terdapat embelajaran yang dilakukan di salah satu SLB yang melaksanakan kegiatan bertani dalam salah satu kegiatan pembelajarannya, khususnya bagi peserta didik tunanetra. SLB Agro Industri merupakan Sekolah Luar Biasa yang melaksanakan pendidikan bagi anak berkebutuhan khusus, salah satunya peserta didik tunanetra. Sekolah ini mempunyai kelebihan dari sekolah-sekolah 
lainnya. Sekolah ini mempunyai suatu kegiatan pembelajaran yang cukup berbeda dari sekolah lainnya, yaitu adanya kegiatan pembelajaran bertani bagi peserta didik tunanetra pada semua jenjang.

Berdasarkan latar belakang adanya SLB Agro Industri ini, dapat dikatakan bahwa SLB ini merupakan SLB pertama yang mengadakan pembelajaran bertani bagi peserta didik tunanetra. Hal ini dilihat dari awalnya SLB ini merupakan tempat pelatihan bagi tunanetra yang melaksanakan kegiatan Latihan Kerja Pertanian Tunanetra (LKPT). LKPT ini didirikan oleh Yayasan Penyantun Wyata Guna (YPWG) pada bulan April 1977. LKPT ini menyelenggarakan pelatihan bagi para tunanetra baik pria maupun wanita yang berusia antara 17 sampai 35 tahun. Lama pendidikan yang dilaksanakan yaitu selama 9 bulan. Seiring berjalannya waktu, dari tahun 2006 ke 2009 yayasan tidak hanya ingin menyelenggarakan pelatihan pertanian bagi para Tunanetra saja, tetapi ingin menyelenggarakan pelatihan bagi semua anak berkebutuhan khusus. Sehingga dibukalah pendidikan secara formal yang bernama SLB Agro Industri yang melaksanakan pendidikan bagi semua ABK, termasuk tunanetra. Selain itu, program kegiatan bertani yang dilaksanakan di SLB Agro Industri ini sangat didukung oleh lingkungan sekitar sekolah yang merupakan daerah pertanian dan sekolah tersebut memiliki lahan pertanian yang cukup luas. SLB Agro Industri ini berlokasi di daerah Kampung Paratag, Desa Jambudipa Kecamatan Cisarua Kabupaten Bandung Barat. Oleh karena itu, SLB ini dapat dikatakan sebagai SLB pertama yang mengadakan program kegiatan bertani bagi para Tunanetra.

Warga negara yang memiliki kelainan atau kebutuhan khusus pun memiliki hak untuk memperoleh pendidikan seperti yang tertuang pada UU No.20 Tahun 2003 tentang Sistem Pendidikan Nasional Pasal 5 ayat 2 bahwa "Warga negara yang mempunyai kelainan fisik, emosional, mental, intelektual, dan/atau sosial berhak memperoleh pendidikan khusus". Pendidikan untuk peserta didik dengan kebutuhan khusus (student with special needs) membutuhkan suatu pola tersendiri sesuai dengan kebutuhan dari masingmasing peserta didik. Hal ini dikarenakan setiap peserta didik mempunyai karakter dan kebutuhan yang berbeda antara satu dengan lainnya. Pendidikan khusus bagi warga negara yang mempunyai kelainan dilaksanakan oleh lembaga pendidikan yang biasa disebut dengan Sekolah Luar Biasa (SLB).

\section{METODE PENELITIAN}

Metode penelitian merupakan cara yang digunakan untuk mendapatkan data yang sesuai dengan kebutuhan. Metode yang digunakan dalam penelitian ini yaitu metode penelitian deskriptif dengan pendekatan kualitatif. Hal ini berdasarkan pertimbangan mengenai tujuan dari penelitian ini yaitu untuk mengetahui gambaran yang mendalam mengenai kegiatan pembelajaran bertanipada siswa tunanetra di SLB Agro Industri Cisarua Kabupaten Bandung Barat, sedangkan jenis data yang digunakan yaitu data yang berbentuk deskripsi dalam katakata atau kalimat.

Teknik pengumpulan data dalam penelitian ini menggunakan tiga teknik, diataranya wawancara, observasi, dan studi dokumentasi. Subjek penelitian dalam penelitian ini terdiri dari lima orang, yaitu kepala SLB Agro Industri, dua orang guru, satu siswa, dan satu orang tua siswa. Peneliti menggunakan triangulasi teknik untuk menguji keabsahan data hasil penelitian. Dalam menguji keabsahan data, peneliti membandingkan data hasil wawancara dengan data hasil observasi dan studi dokumentasi yang bertujuan untuk 
mendapatkan informasi sebagai pembanding untuk kesesuaian data.

\section{HASIL PENELITIAN}

\section{Visi dan Misi SLB Agro Industri}

Berdasarkan hasil penelitian mengenai visi misi SLB Agro Industri, secara garis besar visi misi SLB Agro Industri menekankan pada kemandirian peserta didik agar dapat beradaptasi di lingkungan masyarakat. Berikut pembahasan mengenai visi misi SLB Agro Industri.

Setiap instansi ataupun organisasi pasti memiliki visi dan misi dalam menentukan arah kebijakan dan karakteristik instansi ataupun organisasi tersebut. Visi merupakan suatu gambaran tentang suatu hal yang ingin diwujudkan dalam kurun waktu tertentu. Sedangkan misi merupakan tidakantindakan ataupun upaya-upaya yang dilakukan untuk mewujudkan visi yang diinginkan. Begitu juga sekolah, setiap sekolah pasti memiliki visi misi yang dirumuskan untuk mewujudkan suatu sekolah yang berkualitas. Berdasarkan hal tersebut, setiap sekolah pastinya memiliki visi dan misi. Begitu pula SLB Agro Industri yang memiliki visi dan misi sebagai berikut:

a. Visi

Menjadi lembaga pendidikan yang profesional dan fungsional terhadap peserta didik sehingga mampu mandiri dan beradaptasi (bersilaturahim) dengan masyarakat.

b. Misi
1) Terampil dalam mempertahankan hidup di masyarakat,
2) Terampil dalam merawat diri,
3) Cakap dalam hubungan antar pribadi,

4) Terampil dalam keterampilan yang berhubungan dengan kerja, dan

5) Terampil interpreneur bidang Agro Industri.

Berdasarkan visi yang tertulis di atas, terlihat bahwa SLB Agro Industri ini merupakan salah satu SLB yang mengedepankan kemandirian peserta didik agar dapat terampil bertahan hidup di tengah-tengah masyarakat. Melihat visi tersebut, SLB Agro Industri ini memiliki beberapa misi yang dapat mendukung terwujudnya visi tersebut. Untuk mewujudkan visi tersebut SLB Agro Industri melakukan pembelajaran yang mengutamakan pengembangan kemampuan dan potensi peserta didik dalam merawat diri agar dapat bersosialisasi dan beradaptasi dengan lingkungan sekitar. Hal tersebut dilakukan agar peserta didik merasa lebih percaya diri dalam bersosialisasi dengan lingkungan sekitarnya. Terdapat beberapa kegiatan yang dilakukan untuk mewujudkan visi tersebut. Melalui kegiatan pembelajaran yang dilakukan di SLB Agro Industri diharapkan agar para peserta didik dapat bertahan hidup di tengah masyarakat salah satunya dengan cara mengembangkan kemampuan kewirausahaan siswa. Kemampuan kewirausahaan siswa penting untuk dikembangkan dalam diri peserta didik agar melalui kemampuan kewirausahaan tersebut peserta didik dapat menghasilkan sesuatu, misalnya rupiah untuk mendukung dan membantu memenuhi kubutuhan diri sendiri maupun kebutuhan keluarganya.

Berdasarkan hal di atas, dapat dikatakan bahwa SLB Agro Industri merupakan sekolah yang berkualitas karena memiliki visi misi. Hal ini sesuai dengan yang dikemukakan oleh Heru 
(2010), yang mengemukakan "untuk mewujudkan sekolah yang berkualitas, harus diawali dengan perencanaan strategis yang berkualitas. Rumusan visi, misi, tujuan, dan program yang merupakan bagian dari perencanaan strategis harus berkualitas".

\section{Kurikulum Bertani yang Diterapkan di SLB Agro Industri}

Berdasarkan hasil penelitian yang telah dilakukan, secara garis besar hasil penelitian mengenai kurikulum yang diterapkan di SLB Agro Industri yaitu kurikulum yang diterapkan yaitu kurikulum fungsional. Untuk kegiatan pembelajaran bertani, kurikulum yang digunakan yaitu kurikulum yang mengacu pada kurikulum pertanian SMK yang disesuaikan dengan kebutuhan anak. Berikut pembahasan mengenai kurikulum yang diterapkan di SLB Agro Industri.

Kurikulum merupakan suatu aspek yang perlu dimiliki setiap sekolah untuk mencapai tujuan pembelajaran yang ditetapkan sekolah. Hal ini dikarenakan kurikulum merupakan seperangkat rencana, acuan, dan pengaturan tertulis mengenai materi, media, dan sumber pembelajaran, serta cara yang digunakan sebagai pedoman dalam pelaksanaan proses pembelajaran. Kurikulum pada suatu sekolah merupakan suatu hal penting yang perlu disusun dengan sebaik mungkin untuk mendukung keberhasilan pencapaian tujuan pendidikan di sekolah tersebut.

Setiap sekolah mempunyai pengembangan kurikulum yang berbedabeda sesuai dengan visi dan misi serta latar belakang sekolah tersebut. Seperti halnya kurikulum yang terdapat di SLB Agro Industri yang mempunyai kurikulum yang dinamakan dengan kurikulum fungsional. Kurikulum ini merupakan kurikulum yang mengacu pada kurikulum dari Dinas Pendidikan, namun kurikulum tersebut dimodifikasi kembali sesuai dengan latar belakang dan visi misi sekolah yang menitikberatkan pada kemandirian peserta didik agar dapat hidup bermasyrakat. Hal tersebut sesuai dengan fungsi kurikulum bagi peserta didik sebagai fungsi persiapan yang dikemukakan oleh Hernawan \& Cynthia (2012, hlm. 10) bahwa “... kurikulum juga diharapkan dapat memepersiapkan siswa untuk dapat hidup dalam masyarakat seandainya karena sesuatu hal, tidak dapat melanjutkan pendidikannya".

Selain kurikulum fungsional, sekolah ini memiliki kurikulum pertanian bagi tingkat SMK yang mengacu pada kurikulum SMK pertanian umumnya. Hal ini dikarenakan belum adanya kurikulum pertanian yang dikhususkan untuk Sekolah Luar Biasa. Kurikulum pembelajaran bertani di SLB Agro Industri mengacu pada kurikulum pertanian SMK umum diramu kembali oleh pihak sekolah yang didampingi oleh manager program pada workshop tahun 2009 dan dikembangkan setiap tahun sehingga menghasilkan indikatorindikator keberhasilan yang menjadi acuan dalam pembelajaran bertani. Kegiatan pembelajaran bertani diterapkan pada semua jenjang di SLB Agro, namun bagi tingkat SD dan SMP pembelajaran bertani termasuk pada ekstrakurikuler sebagai pengenalan saja. Sedangkan untuk tingkat SMK, kegiatan pembelajaran bertani merupakan salah satu mata pelajaran keterampilan vokasional yang harus diikuti oleh peserta didik SMK.

Pengimplementasian kurikulum di SLB Agro Industri diimplementasikan pada sebuah kegiatan pembelajaran yang 
dimulai dari proses perencanaan pembelajaran, pelaksanaan pembelajaran, dan evaluasi pembelajaran. Hal tersebut sesuai dengan yang dikemukakan oleh Knirk dan Gustafson dalam Sobandi (2008, hlm. 152) bahwa "pembelajaran merupakan suatu proses yang sistematis, melalui tahapan rancangan, pelaksanaan, dan evaluasi."

Pada tahap pelaksanaan pembelajaran, di SLB Agro Industri pelaksanaan pembelajarannya menggunakan beberapa komponen pembelajaran seperti tujuan pembelajaran, materi, media, metode, pendekatan, penilaian (evaluasi), dan juga siswa serta guru. Hal tersebut sesuai dengan yang dikemukakan oleh Fathoni \& Riyana (2012, hlm. 137) bahwa "dimana di dalam pembelajaran akan terdapat komponen-komponen sebagai berikut: tujuan, materi/bahan ajar, metode dan media, evaluasi, anak didik/siswa, dan adanya pendidikan/guru."

\section{Sumber Daya Manusia (SDM) yang Terlibat dalam Kegiatan Pembelajaran Bertani di SLB Agro Industri}

Berdasarkan hasil penelitian yang telah dilakukan, secara garis besar sumber daya manusia (SDM) di SLB Agro Industri yaitu terdapat beberapa pihak yang terlibat di SLB Agro Industri, diantaranya guru, manager program pembelajaran bertani, dan beberapa warga masyarakat. Berikut pembahasan mengenai SDM di SLB Agro Industri.

Faktor pendukung berjalannya suatu kegiatan pembelajaran di suatu sekolah adalah adanya keterlibatan dari sumber daya manusia. Sumber daya manusia yang mendukung berjalannya kegiatan pembelajaran di sekolah salah satunya adalah guru. Begitu pun dengan kegiatan pembelajaran di SLB Agro Industri, terdapat delapan orang guru yang terlibat dalam proses pembelajaran di SLB Agro Industri yang berlatar belakang dari bidang pendidikan dengan ijazah S1 Pendidikan Luar Biasa (PLB). Selain delapan orang guru tersebut, kegiatan pembelajaran di SLB Agro Industri melibatkan beberapa ahli pertanian yang merupakan sarjana S1 pertanian yang mendukung kegiatan pembelajaran bertani. Dengan gelar pendidikan tersebut (S1) menunjukkan bahwa guruguru tersebut merupakan guru yang profesional. Hal tersebut sesuai dengan yang dikemukakan oleh Suyono \& Hariyanto (2012, hlm. 185) yaitu berbagai perkembangan kehidupan yang pesat dengan tantangan yang semakin kompleks telah menuntut agar guru selalu bersifat profesional, guru harus memiliki kompetensi tertentu dengan kualifikasi akademik yang layak. Saat ini misalnya sesuai dengan tuntutan perundangan, semua guru mulai dari guru TK/RA sampai guru sekolah menengah (SMA/MA/SMK) dituntut minimal berijazah $\mathrm{S} 1$ ).

\section{Tanggapan Siswa Mengenai Kegiatan Pembelajaran Bertani di SLB Agro Industri}

Berdasarkan hasil penelitian yang telah dilakukan, secara garis besar tanggapan siswa mengenai kegiatan pembelajaran di SLB Agro Industri yaitu kegiatan pembelajaran dirasa siswa sudah menyenangkan karena minat siswa terhadap kegiatan pembelajaran di SLB Agro Industri. Meskipun terdapat hambatan yang dirasakan siswa, yaitu kurangnya teori yang diberikan dalam kegiatan pembelajaran, khususnya kegiatan pembelajaran bertani. Berikut 
pembahasan mengenai tanggapan siswa mengenai kegiatan pembelajaran di SLB Agro Industri.

Siswa merupakan salah satu komponen yang menjadi pusat perhatian dalam kegiatan pembelajaran. Hal ini dikarenakan pembelajaran dilakukan untuk mengembangkan potensi siswa. Setiap siswa pastinya memiliki tanggapan yang berbeda mengenai kegiatan pembelajaran yang diikutinya. Salah satunya seperti tanggapan yang diberikan oleh salah satu siswa SMKLB di SLB Agro Industri yang merasa bahwa kegiatan pembelajaran di SLB Agro Industri sudah cukup bagus. Hal tersebut dikarenakan kegiatan-kegiatan yang terdapat di SLB Agro Industri sesuai dengan minat siswa, salah satunya adalah kegiatan pembelajaran bertani. Selain itu tanggapan siswa mengenai kegiatan pembelajaran bertani di SLB Tunanaetra Agro Industri, siswa merasa kegiatan pembelajaran bertani di SLB sudah cukup baik. Hal ini dikarenakan selain mengembangkan kemampuan bertani, sekolah juga mengembangkan kemampuan siswa dalam memasarkan hasil panen dari kegiatan bertani tersebut.

Hal tersebut menunjukkan bahwa SLB Agro Industri dapat dikatakan sebagai suatu sekolah yang baik, karena mengembangkan keterampilan sesuai dengan kebutuhan, kemampuan, dan minat peserta didik. Hal ini sesuai dengan yang dikemukakan oleh Dinas Pendidikan Provinsi jawa Barat Bidang Pendidikan Luar Biasa mengenai analisis materi keterampilan (2010, hlm. 10) yang mengemukakan "kebutuhan/kelainan, kemampuan, minatdan bakat peserta didik merupakan hal yang sangat penting untuk diperhatikan dalam memilih jenis keterampilan yang dikembangkan di sekolah."
Setiap kegiatan pembelajaran, selain adanya kelebihan kegiatan pembelajaran tersebut, tentunya ada hambatan yang dirasakan. Hambatan yang dirasakan siswa dalam kegiatan bertani adalah kurangnya teori tentang pertanian yang diberikan, serta kesulitan siswa dalam pelaksanaan kegiatan bertani yaitu saat penyiraman maupun saat penyemprotan pupuk. Siswa kesulitan dalam menentukan bagian mana yang sudah tersiram dan bagian mana yang belum tersiram. Hal ini dikarenakan hambatan siswa yang merupakan tunanetra, sehingga mereka memiliki keterbatasan dalam indera penglihatan yang menyebabkan mereka kesulitan dalam mendeteksi objek pada jarak yang jauh. Hal tersebut sesuai dengan yang dikemukakan oleh Somantri (2007, hlm. 67) bahwa "indera penglihatan adalah salah satu indera penting dalam meneria informasi yang datang dari luar dirinya. Sekalipun cara kerjanya dibatasi oleh ruang, indera ini mampu mendeteksi objek pada jarak yang jauh."

\section{Tanggapan Orangtua Terhadap Kegiatan Pembelajaran Bertani di SLB Agro Industri}

Berdasarkan hasil penelitian yang telah dilakukan, secara garis besar tanggapan orangtua terhadap kegiatan pembelajaran di SLB Agro Industri yaitu orangtua mendukung kegiatan pembelajaran di SLB Agro Industri. Orangtua sering terlibat dan membantu dalam kegiatan yang diadakan sekolah. Berikut pembahasan mengenai tanggapan orangtua terhadap kegiatan pembelajaran di SLB Agro Industri.

Keberlangsungan kegiatan pembelajaran di sekolah tidak hanya memerlukan dukungan dari guru atau siswa. Tetapi dukungan dari orangtua siswa pun cukup mempengaruhi keberlangsungan kegiatan pembelajaran. Kurangnya dukungan dari orangtua dapat 
menghambat berlangsungnya kegiatan pembelajaran. Namun hal tersebut tidak terjadi di SLB Agro Industri. Sejauh ini para orangtua siswa mendukung kegiatan pembelajaran yang dilaksanakan di SLB Agro Industri. Dukungan tersebut terlihat dari adanya orangtua siswa yang terkadang membantu sekolah dalam pengadaan bibit tanaman untuk praktek kegiatan pertanian. Selain itu, bentuk dukungan orangtua terhadap kegiatan pembelajaran di SLB Agro Industri adalah adanya kerjasama dengan para orangtua siswa yang mendukung kegiatan pembelajaran dengan menerapkan apa yang pelajari di sekolah untuk dilakukan kembali di rumah.

\section{Dukungan Lingkungan Sekitar Sekolah atau Masyarakat Terhadap Kegiatan Pembelajaran Bertani di SLB Agro Industri}

Berdasarkan hasil penelitian yang telah dilakukan, secara garis besar dukungan lingkungan sekitar sekolah atau masyarakat terhadap kegiatan pembelajaran di SLB Agro Industri yaitu masyarakat mendukung kegiatan pembelajaran di SLB Agro Industri, terdapat beberapa warga masyarakat yang terlibat dalam pengelolaan di SLB Agro Industri. Selain itu terdapat beberapa kerjasama yang dijalin SLB Agro Industri. Berikut pembahasan mengenai dukungan lingkungan sekitar sekolah atau masyarakat terhadap kegiatan pembelajaran di SLB Agro Industri.

Setiap sekolah biasanya berada di tengah-tengah masyarakat. Oleh karena itu, setiap sekolah pastinya memerlukan dukungan dari lingkungan sekitar sekolah atau masyarakat dalam pelaksanaan kegiatan pembelajarannya. Dukungan dari lingkungan sekitar sekolah atau masyarakat merupakan salah satu hal yang tidak dapat dilupakan dalam pelaksanaan kegiatan pembelajaran di suatu sekolah, karena meskipun secara tidak langsung selalu ada bantuan dari lingkungan sekitar atau masyarakat terhadap kegiatan pembelajaran di sekolah. Meskipun tidak semua masyarakat selalumemberikan dukungan yang positif terhadap suatu sekolah, pastinya selalu ada pandangan negatif terhadap kegiatan pembelajaran di suatu sekolah. Seperti dukungan dari masyarakat sekitar SLB Agro Industri yang cukup mendukung kegiatan pembelajaran di SLB Agro Industri. Namun, terdapat pula sebagian masyarakat yang masih memiliki anggapan tradisional yang menganggap bahwa ABK harus selalu dikasihani dan tidak dapat hidup mandiri.

Selain dukungan dari masyarakat sekitar sekolah, suatu sekolah pun perlu memiliki hubungan kerjasama dengan pihak lain yang dapat mendukung kegiatan pembelajaran di sekolah tersebut. Seperti SLB Agro Industri yang tidak hanya mendapatkan dukungan dari masyarakat sekitar, namun menjalin kerjasama dengan beberapa industri yang bergerak dalam bidang pertanian untuk mendukung kegiatan pembelajaran.

\section{E. SIMPULAN DAN SARAN}

1. Berdasarkan hasil temuan mengenai visi misi SLB Agro Industri yang menekankan pada kemandirian peserta didik agar dapat beradaptasi di lingkungan masyarakat, maka peneliti merekomendasikan seyogyanya pihak sekolah mengembangkan visi dan misi yang diterapkan di sekolah sesuai dengan perkembangan dalam kehidupan masyarakat, agar peserta didik mampu untuk beradaptasi dalam kehidupan bermasyarakat.

2. Berdasarkan hasil temuan mengenai kurikulum yang diterapkan di SLB Agro Industri, ditemukan bahwa belum 
adanya kurikulum pertanian bagi SMKLB, sehingga peneliti merekomendasikan seyogyanya pihak sekolah mengusulkan kepada pemerintah untuk mengeluarkan kurikulum pertanian khusus bagi SMKLB agar kegiatan pembelajaran bertani dapat dilaksanakan di semua SLB sebagai keterampilan vokasional bagi peserta didik.

3. Berdasarkan hasil temuan mengenai sumber daya manusia (SDM) yang terlibat dalam kegiatan pembelajaran bertani di SLB Agro Industri, ditemukan bahwa terdapat banyak pihak yang terlibat dalam pelaksanaan kegiatan pembelajaran di SLB Agro Industri. Namun, dalam pelaksanaan kegiatan pembelajaran bertani, belum ada ahli pertanian khusus sebagai tenaga pengajar dalam kegiatan pembelajaran tersebut. Sehingga peneliti merekomendasikan seyogyanya sekolah dapat membentuk team work yang terdiri dari guru dan ahli pertanian yang tidak hanya sebagai manager program, tetapi sebagai pengajar di lapangan khususnya dalam kegiatan pembelajaran bertani untuk mendukung ketercapaian tujuan yang diinginkan.

4. Berdasarkan hasil temuan mengenai tanggapan siswa mengenai kegiatan pembelajaran bertani di SLB Agro Industri, ditemukan tanggapan siswa bahwa siswa merasa kurangnya teori yang diberikan dalam kegiatan pembelajaran khususnya kegiatan pembelajaran bertani. Sehingga peneliti merekomendasikan seyogyanya guru melaksanakan pemberian teori mengenai kegiatan bertani tidak hanya disampaikan pada saat praktek di lahan saja, tetapi terdapat jam pelajaran khusus untuk pemberian teori tentang pertanian.Sehingga para peserta didik tidak hanya mendalami praktek kegiatan bertani saja, tetapi mengetahui juga teori mengenai kegiatan yang dilakukan tersebut.

5. Berdasarkan hasil temuan mengenai tanggapan orangtua terhadap kegiatan pembelajaran bertani di SLB Agro Industri, dapat dikatakan adanya dukungan dari orangtua terhadapkegiatan pembelajaran di SLB Agro, khususnya dalam kegiatan pembelajaran bertani seperti bantuan pengadaan bibit, dan pembudidayaan philodendron. Namun peneliti merekomendasikan seyogyanya orangtua mengadakan kerjasama pula untuk membimbing peserta didik dalam pemasaran hasil budidaya tanaman yang telah dilakukan.

6. Berdasarkan hasil temuan mengenai dukungan lingkungan sekitar atau masyarakat terhadap kegiatan pembelajaran bertani di SLB Agro Industri, ditemukan bahwa lingkungan sekitar atau masyarakat mendukung kegiatan pembelajaran di SLB Agro Industri, dengan adanya keterlibatan warga dalam pengelolaan di SLB Agro Industri. Selain itu, pihak sekolah telah menjalin beberapa kerjasama dengan industri pertanian. Berdasarkan hal tersebut, peneliti merekomendasikan seyogyanya pihak sekolah meningkatkan kerjasama dengan pihak yang telah terjalin sehingga dukungan dari masyarakat maupun industri pertanian terhadap kegiatan pembelajaran di sekolah dapat semakin meningkat.

\section{DAFTAR PUSTAKA}

AAK. (2012). Hijauan Makanan Ternak. Yogyakarta: Kanisius. 
Banoewidjojo, M. (1983). Pembangunan Pertanian. Malang: Openi.

Dimyati \& Mudjiono. (2009). Belajar dan Pembelajaran. Jakarta: PT. Rineka Cipta.

Dinas Pendidikan Provinsi Jawa Barat Bidang Pendidikan Luar Biasa. (2011). Keterampilan SMALB. Bandung: Depdikbud.

Dinas Pendidikan Provinsi Jawa Barat Bidang Pendidikan Luar Biasa. (2010). Panduan Pelaksanaan Pendidikan Keterampilan untuk $A B K$. Bandung: Depdikbud.

Fathoni, T. \& Riyana C. (2012). Komponenkomponen Pembelajaran. Dalam Tim Pengembang MKDP Kurikulum dan Pembelajaran. (2012). Kurikulum dan Pembelajaran. (hlm. 1-13). Jakarta: PT. Rajagrafindo Persada.

Hanafiah, N. \& Suhana C. (2012). Konsep Strategi Pembelajaran. Bandung: PT. Refika Aditama.

Hernawan H. \& Cynthia R. (2012). Pengertian, Dimensi, Fungsi, dan Peranan Kurikulum. Dalam Tim Pengembang MKDP Kurikulum dan Pembelajaran. (2012). Kurikulum dan Pembelajaran. (hlm. 1-13). Jakarta: PT. Rajagrafindo Persada.

Heru. (2010). Merumuskan Visi, Misi, Tujuan, dan Program Sekolah. [Online]. Tersedia di: http://heruizzuddin.blogspot.com /2010/04/merumuskan-visimisitujuan-dan-program.html. Diakses 10 Juli 2014.

Hosni, I. (Tanpa tahun). Buku Ajar Orientasi dan Mobilitas. Departemen Pendidikan dan Kebudayaan: Tidak Diterbitkan.
Iswantoro. (2010). Menyiapkan Bibit Tanaman Hortikultura. [Online]. Tersedia di: http://iswantoroiswantorogegen.blogs pot.com/20 10/12/menyiapkanbibittanaman-hortikultura.html. Diakses 12 Juni 2014.

Komalasari, K. (2010). Pembelajaran Kontekstual:Konsep dan Aplikasi. Bandung: PT. Refika Aditama.

Mangunwidjaja, D. (2008). Pengantar Teknologi Pertanian. Jakarta: Penebar Swadaya.

Mardalis. (2003). Metode Penelitian Suatu Pendekatan Proposal. Jakarta: Cipta Karya.

Moleong, L. J. (2012). Metodologi Penelitian Kualitatif edisi revisi. Bandung: PT. Remaja Rosdakarya.

Nawawi, A. (Tanpa tahun). Low Vision Handout. Jurusan Pendidikan Luar Biasa UPI: Tidak Diterbitkan.

Nurmala, T. dkk. (2012). Pengantar Ilmu Pertanian. Yogyakarta: Graha Ilmu.

Purnamawati, N. S. (2005). Sikap Mahasiswa Jurusan PLB UNJ terhadap Mahasiswa Tunanetra Jurusan PLB UNJ. Jurusan Pendidikan Luar Biasa UPI: Tidak Diterbitkan.

Pusat Bahasa Departemen Pendidikan Nasional. (2005). Kamus Besar Bahasa Indonesia (third ed.). Jakarta: Balai Pustaka.

Rahardja, D. \& Sujarwanto. (2010). Pengantar Pendidikan Luar Biasa (Orthopedagogik). UD. Surabaya: UD. Mapan.

Rahardja, D. (2010). Sistem Pengajaran Modul Orientasi dan Mobilitas 
(SPMOM). Jurusan Pendidikan Luar Biasa UPI: Tidak Diterbitkan.

Rahim, S. (2013). Jenis-Jenis Pengolahan Tanah. [Online]. Tersedia di: http://mekanisasi suplirahim.blogspot.com/2013/0 5/jenis-jenis-pengolahan tanah.html. Diakses 12 Juni 2014.

Sarief, S. (1985). Ilmu Tanah Pertanian. Bandung: Pustaka Buana.

Sarief, S. (1989). Fisika-Kimia Tanah Pertanian. Bandung: Pustaka Buana.

Sarief, S. (1989). Kesuburan dan Pemupukan Tanah Pertanian. Bandung: Pustaka Buana.

Setiawan, A. (1993). Sistem Pengajaran Orientasi dan Mobilitas. Pusat Pelatihan Orientasi dan Mobilitas IKIP Bandung:Tidak Diterbitkan.

SMK PK-LK Agro Industri. (Tanpa tahun). Teknik Budidaya Tanaman. Bandung: Tidak Diterbitkan.

Sobandi, B. 2008. Model Pembelajaran Kritik dan Apresiasi Seni Rupa. Direktorat Jendral Pendidikan Tinggi.

Somantri, T. S. (2007). Psikologi Anak Luar Biasa. Bandung: PT. Refika Aditama.

Sudiati, S. (1992). Korelasi Pengetahuan dan Keterampilan Orientasi dan Mobilitas Terhadap Kemampuan Bertani Bagi Tunanetra di LKPT Yayasan Penyantun Wyata Guna CisaruaBandung. Pendidikan Luar Biasa UPI: Tidak Diterbitkan.

Sugiyono. (2009). Metode Penelitian Kuantitatif Kualitatif dan $R \& D$. Bandung: Alfabeta.

Sugiyono. (2010). Metode Penelitian Kuantitatif Kualitatif dan $R \& D$. Bandung: Alfabeta.
Sugiyono. (2012). Memahami Penelitian Kualitatif. Bandung: Alfabeta.

Suyono \& Hariyanto. (2012). Belajar dan Pembelajaran. Bandung: PT. Remaja Rosdakarya.

Tarsidi, D. (2008). Dampak Ketunanetraan terhadap Perkembangan Keterampilan Sosial Anak. Tersedia di: http://dtarsidi.blogspot. com/2008/01/dampakketunanetraanterhadap.html. Diakses 04 Juli 2014.

Tarsidi, D. (2009). Pendidikan Anak Tunanetra I Kompilasi Materi Perkuliahan. Jurusan Pendidikan Luar Biasa UPI: Tidak Diterbitkan.

Tarsidi, D. (2011). Definisi Tunanetra. [Online]. Tersedia di: http://dtarsidi.blogspot.com/2008/01/d ef inisi-tunanetra.html. Diakses 10 Juni 2014.

Wikipedia. (2014). Pertanian. [Online]. Tersedia di: http://id.wikipedia. org/wiki/Pertanian. Diakses 11 Juni 2014 . 